\title{
Functional localization of ion channel densities from calcium fluorescence
}

\author{
Jay H Raol, Steven J Cox \\ From Nineteenth Annual Computational Neuroscience Meeting: CNS*2010 \\ San Antonio, TX, USA. 24-30 July 2010
}

Single cells learn by tuning their synaptic conductances and redistributing their excitable machinery. To reveal its learning rules, one must therefore know how the cell remaps its ion channels in response to physiological stimuli. We exploit the recent ability to dynamically monitor cytosolic dye-buffered calcium, throughout rat hippocampal pyramidal cells in slice, with sub-millisecond temporal resolution and sub-micron spatial resolution [1] in the construction of a functional map of calcium and potassium channel densities.

In the process we pose and solve [2] a number of inverse problems associated with converting dye recordings to current and voltage information through a series of experimental procedures:

(1) Focal uncaging of cytosolic calcium in the presence of dye to determine dye kinetics and intracellular calcium extrusion rates,

(2) Suprathreshold current injection at the soma to infer calcium current from calcium fluorescence using (1),

(3) Recovery of the calcium channel density and voltage information from the calcium current in (2),

(4) Recovery of various potassium channel densities through voltage information in (3) and the selective use of potassium channel blockers.

We demonstrate the validity of this algorithm on synthetic data generated from channel densities and morphologies consistent with previous experimental results [3]. Finally, we explore the robustness of this algorithm to experimental error and noise.

* Correspondence: raol@rice.edu

Computational and Applied Mathematics, Rice University, Houston, TX, 77005, USA

\section{Acknowledgements}

Biomedical Discovery Training Program of the W. M. Keck Center for Interdisciplinary Bioscience Training of the Gulf Coast Consortia (NIH Grant No. 1 T90 DA022885 and 1 R90 DA023418) and VIGRE award to the departments of Computational and Applied Mathematics, Math and Statistics (NSF DMS-0240058)

Published: 20 July 2010

\section{References}

1. lyer $V$, Hoogland $T$, Saggau P: Fast functional imaging of single neurons using random-access multiphoton microscopy. J Neurophysiol 2006, 95(1):535-545.

2. Cox SJ: An adjoint method for channel localization. Math Med Bio/ 2006, 23(2):139-152.

3. Magee JC: Dendritic voltage-gated ion channels. Dendrites New York: Oxford Univ. PressStuart G, Spruston N, Hauser M. , 2nd 2008, 225-250.

doi:10.1186/1471-2202-11-S1-P155

Cite this article as: Raol and Cox: Functional localization of ion channel densities from calcium fluorescence. BMC Neuroscience 2010 11(Suppl 1): P155.
Submit your next manuscript to BioMed Central and take full advantage of:

- Convenient online submission

- Thorough peer review

- No space constraints or color figure charges

- Immediate publication on acceptance

- Inclusion in PubMed, CAS, Scopus and Google Scholar

- Research which is freely available for redistribution

Submit your manuscript at www.biomedcentral.com/submit
C Biomed Central 